\title{
EMISI GAS RUMAH KACA DI PERKEBUNAN KARET
}

\author{
Greenhouse Gas Emissions in the Rubber Plantation
}

\author{
Priyo Adi Nugroho
}
Pusat Penelitian Karet- Balai Penelitian Sungei Putih, Sungei Putih, Galang Deli Serdang Po Box 1415, Medan 20001
Email: priyo.nugroho@puslitkaret.co.id

Diterima 14 Desember 2015 / Direvisi 18 November 2016 / Disetujui 2 Desember 2016

\begin{abstract}
Abstrak
Karbondioksida $\left(\mathrm{CO}_{2}\right)$, dinitrogen oksida $\left(\mathrm{N}_{2} \mathrm{O}\right)$ dan metan $\left(\mathrm{CH}_{4}\right)$ adalah gas-gas penting di atmosfer yang berkaitan dengan pemanasan global. Sektor pertanian menyumbangkan 10$14 \%$ dari total gas rumah kaca (GRK)yang berasal dari aktivitas manusia (antropogenik). Dinamika penelitian GRKpada perkebunan karet di Indonesia memang tidak secepat komoditas perkebunan lainnya(seperti padi dankelapa sawit) dan relatif tertinggal dengan beberapa negara produsen karet di dunia. $\mathrm{CO}_{2}$ dalam kaitannya dengan cadangan karbon adalah topik yang menarik dan banyak diteliti. Metode Biometric dan eddy covariance sering digunakan dalam mengukur emisi karbon. Hasil penelitian menggunakan kedua metode tersebut menunjukkan bahwa ekosistem perkebunan karet cenderung melepaskan karbon yang jauh lebih kecil dibandingkan dengan penyerapannya. Jumlah $\mathrm{Co}_{2}$ yang diserap oleh perkebunan karet untuk setiap hektarnyaberkisar antara 29-40ton /hektare/tahun. Penelitian tersebut umumnya dilakukan pada lahan yang sudah establish artinya belum dikaitkan dengan berbagai perlakuan seperti dosis pemupukan, bahan organik, waktu pemupukan, dan pengolahan tanah. Penelitian lebih mendalam mengenai emisi karbon yang berkaitan dengan kultur teknis sangatdiperlukan dengan tujuan untuk
\end{abstract}

mencari teknis budidaya yang paling tepat serta aman bagi lingkungan.Penelitian tentang gas $\mathrm{N}_{2} \mathrm{O}$ di perkebunan karet juga masih perlu dilakukan karenajumlah nitrogen dan bahan organik setiap tahunnya cukup besar.

Kata kunci: Hevea brasiliensis, $\mathrm{CO}_{2}, \mathrm{~N}_{2} \mathrm{O}$, sequestrasikarbon, eddy covariance

\section{Abstract}

Carbon dioxide $\left(\mathrm{CO}_{2}\right)$ and nitrous oxide $\left(\mathrm{N}_{2} \mathrm{O}\right)$ and methane $\left(\mathrm{CH}_{4}\right)$ were important gases in the atmosphere, which associated with global warming. The agricultural sector contributes $10-14 \%$ of thetotal greenhouse gases (GHG) from human activity (athropogenic). The dynamics of $G H G$ researchon rubber plantations in Indonesia is not as fast as other comodities (such as palm oil and rice) and relatively underdeveloped with some rubber producing countries in the world. $\mathrm{CO} 2$ in relation to the carbon stock is an interesting topic and any researched. Biometric and eddy covariance methods were often used in measuring carbon emissions. The results of research using both methods showed that ecosystems of rubber plantations tended smaller of carbon releation than the absorption. The total of $\mathrm{CO} 2$ absorbed by the rubber plantations between 29-40 tons / hecter/year. Generally, the study conducted on establish land, its mean has not been associated with a variety of treatments such as fertilizer doses, organic materials, time of fertilization and soil tillage. Complecated 
research about carbon emissions in related to culture teqnique have necessary. The purpose to find out of technical cultivation of most appropriate and friendly to environment. Also, the similar research about N2O gasneeds to be done becausethe total of nitrogen and organic material in the rubber plantations is a lot peryear.

Keywords: Hevea brasiliensis, $\mathrm{CO}_{2}, \mathrm{~N}_{2} \mathrm{O}$, carbon sequestration, eddy covariance

\section{Pendahuluan}

Gas rumah kaca (GRK) merupakan isu yang cukup mengemuka dalam beberapa dekade terakhir. Intergovernmental Panel on Climate Change (2007) melaporkan bahwa telah terjadi kenaikan volume gas rumah kaca (GRK) secara signifikan di atmosfer sejak era industri akibat aktivitas manusia (antropogenik). Karbondioksida $\left(\mathrm{CO}_{2}\right)$, dinitrogen oksida $\left(\mathrm{N}_{2} \mathrm{O}\right)$ dan metan $\left(\mathrm{CH}_{4}\right)$ adalah tiga gas utama yang menjadi perhatian banyak peneliti. Sektor pertanian menyumbangkan $10-14 \%$ dari total gas yang berasal dari antropogenik.

Salah satu komoditas komersial yang cukup penting di dunia adalah karet (Hevea brasiliensis). Food and Agriculture Organization (2006) menyebutkan bahwa sekitar 32\% dari total luasan perkebunan karet di dunia berada di Indonesia. Sebagai negara dengan luasan tanaman karet terbesar di dunia maka Indonesia harus dapat mengikuti perkembangan isu dunia dalam kaitannya dengan emisi GRK. Wacana mengenai carbon trading yang dilontarkan oleh International Rubber Research Development Board (IRRDB) pada beberapa tahun lalu harus didukung dengan data-data penelitian yang akurat. Tetapi biaya yang relatif tinggi terkait penelitian GRK adalah suatu tantangan yang harus dihadapi.

Di dalam budidaya tanaman, pupuk dan bahan organik diaplikasikan di areal untuk menstimulasi pertumbuhan dan meningkatkan hasil. Aplikasi pupuk dan bahan organik akan mempengaruhi produksi bersih biomasa (NPP), jumlah bahan organik tanah, aktivitas mikroorganisme tanahyang pada gilirannya akan mempengaruhi produksi $\mathrm{CO}_{2}$ dan $\mathrm{N}_{2} \mathrm{O}$ dari dalam tanah (Shimizu et al., 2009; Gong et al., 2009; Nhu et al., 2012; Shimizu et al., 2013). Proses pembentukan $\mathrm{CO}_{2}$ dan $\mathrm{N}_{2} \mathrm{O}$ di dalam tanah sangat di pengaruhi oleh soil climate (suhu dan kandungan air tanah), sumber karbon (C), nutrisi, ketersediaan oksigen, dan faktor biologi (Risk etal., 2013).

Walaupun penelitian mengenai emisi GRK asal perkebunan karet di Indonesia relatif kurang populer dan tertinggal dengan negara lain namun hasil-hasil penelitian emisi GRK yang sudah ada cukup penting untuk dipahami dan dijadikan dasar untuk penelitian selanjutnya. Tulisan ini membahas mengenai emisi gas rumah kaca di perkebunan karet berdasarkan hasil penelitian dan studi literatur.

\section{Emisi $\mathrm{CO}_{2}$ dan $\mathrm{N}_{2} \mathrm{O}$}

Permasalahan emisi GRK terutama $\mathrm{CO}_{2}$ terkadang masih menimbulkan perdebatan karena adanya ketidaksamaan persepsi. Banyak orang mendifinisikan emisi sebagai gas yang dilepaskan tanah ke atmosfer. Padahal sebelum dilepaskan ke atmosfer gas tersebut di serap dahulu oleh tanaman. Terkadang kondisi tersebut tidak di pertimbangkan sehingga menimbulkan perbedaan dalam perhitungan besarnya emisi. Dengan melibatkan faktor tanah dan tanaman, Kirschbaum et al. (2001) mendifinisikan emisi $\mathrm{CO}_{2}$ dengan sangat baik dan komprehensif (Gambar 1).

Pada Gambar 1 terlihat bahwa fiksasi karbon oleh tanaman terjadi melalui fotosintesis dan hasil dari fiksasi ini disebut dengan Gross Primary Production (GPP). Diperkirakan setengah dari karbon yang difiksasi hilang dalam metabolisme tanaman lewat respirasi akar dan tajuk (autotrophic respiration). Kehilangan karbon di ekosistem juga terjadi melalui respirasi oleh organisme selain tanaman yang hidup di dalam tanah dan lapisan serasah (heterotropic respiration). Organisme tersebut menguraikan bahan organik yang berasal dari guguran biomasa 


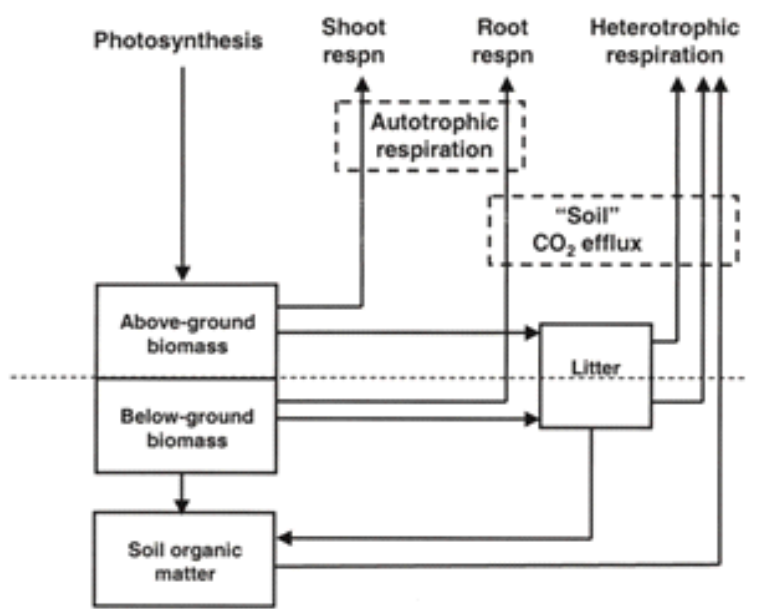

Gambar 1. Diagram aliran karbon di suatu ekosistem (Kirschbaum et al., 2001)

tanaman, kotoran, organisme yang mati dan eksudat akar. Heterotropic respiration juga meliputi karbon yang dilepaskan karena dekomposisi kayu dari tanaman yang masih tegak. Selisih karbon antara GPP dengan autotrophic respiration disebut dengan Net Primary Production (NPP) yang sangat penting dalam perhitungan emisi karbon.

Jumlah $\mathrm{CO}_{2}$ hasil dari autotrophic dan heterotrophic respiration disebut sebagai flux $\mathrm{CO}_{2}$ tanah atau respirasi tanah (soil respiration) yang sering disalahtafsirkan sebagai emisi $\mathrm{CO}_{2}$ Emisi $\mathrm{CO}_{2}$ dalam arti yang sebenarnya adalah selisih antara NPP dengan kehilangan karbon melalui heterotropic respiration yang selanjutnya disebut dengan Net Ecosystem Exchange (NEE) atau Net Ecosystem Production(NEP).
Proses pembentukan dan pelepasan $\mathrm{N}_{2} \mathrm{O}$ sangat berbeda dengan $\mathrm{CO}_{2}$ Emisi $\mathrm{N}_{2} \mathrm{O}$ lebih dipengaruhi oleh proses transformasi kimia di dalam tanah. Kool et al. (2011) mendeskripsikan empat proses utama dalam produksi $\mathrm{N}_{2} \mathrm{O}$ yang melibatkan bakteri (nitrifier dan denitrifier) (Gambar 2) yaitu: $\mathrm{N}_{2} \mathrm{O}$ yang diproduksi melalui proses oksidasi ammonia oleh nitrifier-nitrification (NN), melalui proses nitrit yang di ubah ke $\mathrm{N}_{2} \mathrm{O}$ oleh nitrifierdenitrification (ND), melalui proses reduksi nitrat (yang berasal dari proses nitrifikasi) atau nitrification-coupled denitrification (NCD) oleh denitivifier dan melalui proses reduksi nitrat yang diaplikasikan ke dalam tanah atau fertilizer-denitrification(FD).

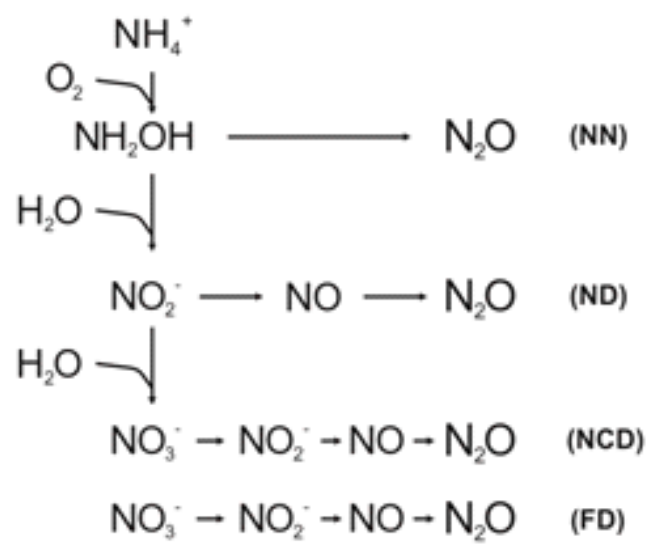

Gambar 2. Gambaran/alur proses utama produksi $\mathrm{N}_{2} \mathrm{O}$ (Kool et al., 2011) 
Jumlah $\mathrm{N}_{2} \mathrm{O}$ yang dilepaskan dari dalam tanah ke atmosfer dapat langsung dikatakan sebagai emisi $\mathrm{N}_{2} \mathrm{O}$ karena tidak terdapat penyerapan gas $\mathrm{N}_{2} \mathrm{O}$ oleh tanaman. Dengan kata lain emisi $\mathrm{N}_{2} \mathrm{O}$ adalah sama dengan flux $\mathrm{N}_{2} \mathrm{O}$.

\section{Metode Pengukuran Emisi}

\section{Pengukuran Emisi $\mathrm{CO}_{2}$ dengan Metode Biometric dan Eddy Covariance}

Terdapat beberapa metode yang sering digunakan oleh para peneliti dalam pengukuran emisi karbon diantaranya biometric dan eddy covariance. Metode biometric adalah mengukur tiap komponen dalam suatu ekosistem yang berfungsi melepaskan karbon maupun yang menyerap karbon (komponen biomassa). Komponen yang melepaskan karbon meliputi autotrophic dan heterotrophic respirationyang diukur menggunakan metode closed chamber (Toma and Hatano, 2007). Prinsip dari metode closed chamber (bilik tertutup) adalah gas yang dilepaskan oleh tanah untuk sementara waktu dikumpulkan di suatu ruang tertutup dengan ukuran tertentu (chamber) dan diukur konsentrasinya pada suatu interval waktu (Gambar 3). Gas yang sudah diambil selanjutnya diukur dengan infra red gas analyzer (IRGA) atau gas chromatography (GC).

Komponen penyerap karbon yang meliputi biomassa di atas permukaan tanah (aboveground biomass), biomassa di atas permukaan tanah yang sudah mati seperti serasah dan cabang yang runtuh serta biomassa di dalam tanah (below-ground biomass) yang terdiri atas akar tanaman yang juga harus dihitung untuk menganalisis neraca karbonnya. Above-ground biomass dapat diestimasi dengan dua metode lapangan yaitu metode destruktif dan nondestruktif. Metode destruktif disebut juga dengan metode pemanenan biomassa dan sering digunakan dalam penelitian pada ekosistem hutan (Gibs et al., 2007). Metode ini dilakukan dengan cara memanen seluruh bagian tanaman seperti batang, cabang dan daun (Chung-Wang and Ceulemans, 2004; Ravindranath and Oswald, 2008) dan mengukur berat keringnya (setelah dioven).

Walaupun allometric dinilai cukup akurat namun pengerjaannya cukup merepotkan. Kemajuan teknologi informasi terutama penginderaan jauh (remote sensing) sangatlah membantu dalam mengestimasi jumlah biomassa tanaman tanpa harus melakukan pengukuran dilapangan seperti pada metode allometric. Penginderaan jauh adalah suatu proses mendapatkan data suatu area atau sebuah fenomena dari kejauhan dengan menganalisisnya melalui suatu instrument tanpa kontak dengan objek. Keuntungan dari penggunaan metode ini adalah peneliti dapat memperoleh informasi dari lokasi yang sulit dijangkau/belum terdapat akses jalan. Penginderaan jauh sangat berguna dalam pemetaan dan monitoring vegetasi, tutupan lahan dan perubahan lahan.

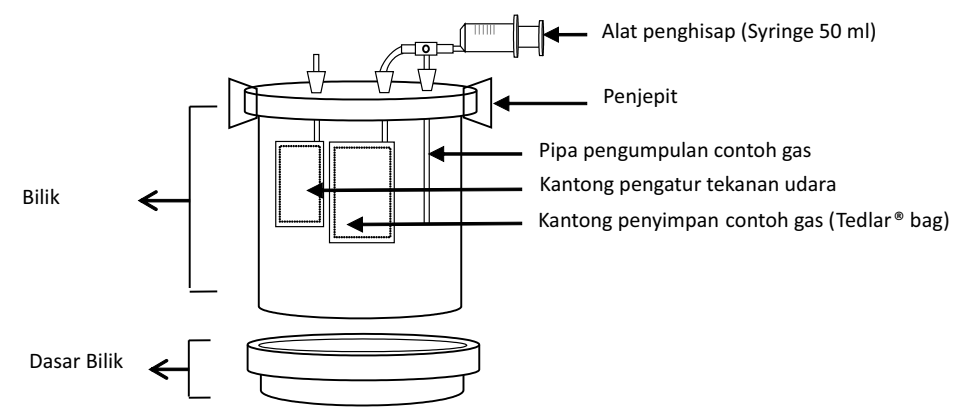

Gambar 3. Skema sebuah closed chamber 
Beberapa penelitian telah dilakukan terkait estimasi biomassa dengan menggunakan remote sensing. Nelson et al. (1988) memanfaatkan laser profiling untuk mengestimasi biomassa dan volume hutan. Steininger.(2000); Lu.(2005) menggunakan citra Landsat TM untuk mengestimasi above ground biomass dari hutan tropis di Bolivia dan Brazil. Lefsky et al. (2001) mengembangkan LiDAR remote sensing. Teknik ini dirancang untuk memancarkan sinyal yang dapat menembus kanopi tanaman. LiDAR systems mengirimkan gelombang dari cahaya laser dan mengukur waktu pengembalian sinyal lalu secara langsung dapat menghitung tinggi dan struktur vertikal hutan.

Net Ecosystem Production (NEP) atau Net Ecosystem Exchange (NEE) yaitu pertukaran net $\mathrm{CO}_{2}$ antara ekosistem dengan atmosfer (Barr et al., 2004). NEP dapat diukur secara langsung dengan menggunakan Eddy Covariance yang merupakan sebuah metode mikrometeorologi yang mana flux $\mathrm{CO}_{2}$, uap air dan kecepatan angin tiga dimensi diukur secara realtime (Baldochi, 2003).

Sistem eddy covariance terdiri atas tiga dimensional sonic anemometer atau alat pengukur angin (CSAT Campbell USA) yang dipasang secara bersama-sama dengan infra red gas analyzer (Li 7500, Li-Cor, USA). Sistem ini juga dilengkapi dengan sebuah jaringan radiometer dan sensor suhu dan kelembaban udara (HMP 45, Vaisala, Finland). Alat-alat tersebut dipasang pada sebuah tower yang diletakkan beberapa meter di atas tajuk tanaman (Gambar 4).

Data-data klimatologi lainnya seperti curah hujan, suhu maksimum-minimum, panjang penyinaran juga diperlukan tetapi dapat diperoleh dari stasiun klimatologi (Annamalainathan et al., 2011). Data hasil pengukuran selanjutnya diolah dengan software tertentu misal Eddy Re-software. Terkadang kendala di lapangan membuat data tidak terekam utuh sehingga diperlukan suatu koreksi agar data yang diperoleh menjadi sempurna. Metode Gaps filling biasanya sering digunakan untuk melengkapi dan mengkoreksi data yang hilang dengan menggunakan persamaan matematis.

\section{Pengukuran emisi $\mathrm{N}_{2} \mathrm{O}$ dengan Closed Chamber}

Pengukuran emisi $\mathrm{N}_{2} \mathrm{O}$ relatif lebih sederhana dibandingkan dengan $\mathrm{CO}_{2}$ Metode Closed chamber (Gambar 3) adalah yang umum digunakan dan prinsipnya sama seperti pengukuran fluks $\mathrm{CO}_{2}$ hanya saja interval waktu pengambilan sample yang relatif lebih

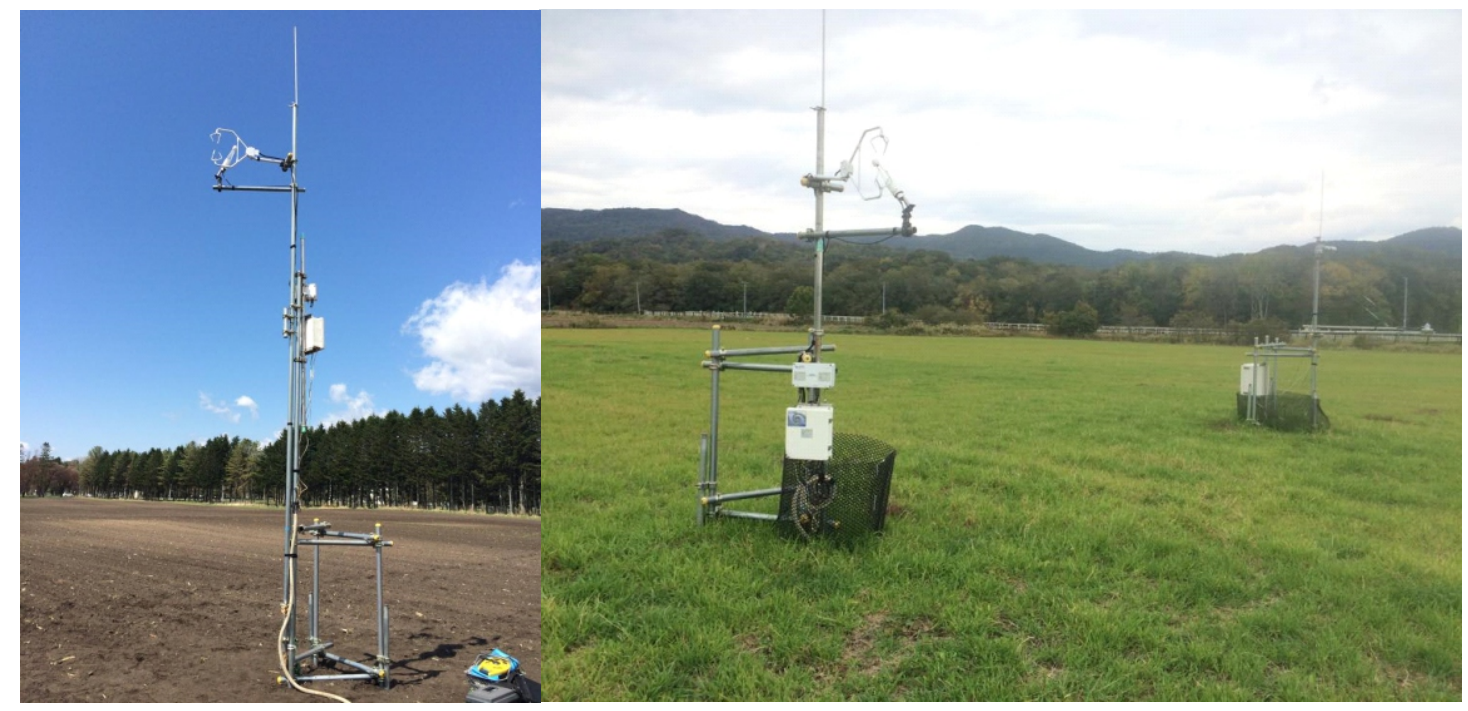

Gambar 4. Eddy covariance tower dipadang rumput 
lama dibandingkan $\mathrm{CO}_{2}$. Jika pengambilan sampel $\mathrm{CO}_{2}$ dilakukan pada interval 0 dan 30 menit maka untuk $\mathrm{N}_{2} \mathrm{O}$ pengambilan sample gas dilakukan pada interval 0,15 dan 30 menit (Nugroho et al., 2015). Gas yang diperoleh lalu dianalisis konsentrasinya menggunakan Gas chromatography (GC) yang dilengkapi dengan Electron Capture Detector(ECD).

\section{Pengukuran gas rumah kaca di perkebunan karet}

Penelitian mengenai emisi karbon di perkebunan karet lebih terfokus pada jumlah cadangan karbon (carbon stock), dalam kaitannya dengan penambatan karbon oleh vegetasi (carbon sequestration). Penelitian di Thailand oleh Chantuma et al. (2012) menunjukkan bahwa setiap bagian tanaman karet mengandung karbon yang berbeda-beda dengan rata-rata $44,52 \%$ dari total kering tanaman.Berat batang dan cabang pada tanaman karet yang berumur 1-20 tahun memiliki proporsi yang paling besar yaitu 71,1$87,5 \%$ dari total kering. Berat tajuk termasuk daun memiliki porsi yang lebih rendah yaitu $1,1-6,7 \%$. Tanaman yang semakin tua akan mengalami peningkatan persentase berat tajuknya misalnya pada umur 15-20 tahun persentase kering daun adalah 2,0-2,3\% dari berat totalnya. Bagian perakaran dan kaki gajah berada pada kisaran 10,3-20,8\% dari total berat kering.

Penelitian ini selanjutnya lebih disempurnakan lagi oleh Saungreksawong et al. (2012) yang menghitung simpanan karbon dalam ekosistem (ecosystem carbon storages). Dalam konteks ini selain karbon yang bersumber dari biomassa, karbon yang berasal dari dalam tanah juga diperhitungkan. Ecosystem carbon storage dari beberapa ekosistem tanaman karet berbagai umur dibandingkan dengan hutan alami disajikan pada Tabel 1.

Kedua penelitian tersebut belum merinci secara detail berapa karbon yang dilepaskan dan yang diserap oleh tanaman karet sehingga data tersebut menjadi kurang sempurna. International Rubber Research and Development Board (2009) menyebutkan bahwa carbon sequestration di beberapa negara produsen karet di dunia cukup besar yaitu 2940 ton karbon/hektar/tahun dan sangat potensial untuk diajukan dalam skema carbon trading (Tabel 2).

Di Indonesia penelitian yang mulai terperinci mengenai neraca karbon telah dilakukan oleh Susilawati (2011) di perkebunan karet klon PR 300 berumur 20, 25 dan 31 tahun yang berlokasi di Cibungur Jawa Barat. Dalam penelitian tersebut besarnya respirasi tanah yang dilepaskan ke udara juga dihitung dengan menggunakan metode penangkapan karbon oleh kalium hidroksida $(\mathrm{KOH})$ dan dititrasi dengan asam klorida $(\mathrm{HCl})$ (Anderson, 1982). Hasil penelitian tersebut menunjukkan bahwa serapan karbon semakin besar seiring dengan pertambahan umur tanaman karet. Sebaliknya laju emisi semakin mengecil (Gambar 5).

Tabel 1. Ecosystem carbon storage dari beberapa ekosistem karet, Eucalyptus dan hutan alami

\begin{tabular}{lrcccc}
\hline \multirow{2}{*}{ Ekosistem } & \multicolumn{2}{c}{ Karbon biomassa } & \multicolumn{2}{c}{ Karbon tanah } & Total \\
\cline { 2 - 6 } & Ton/ha & $\%$ & Ton/ha & $\%$ & Ton/ha \\
\hline Karet 1 tahun & 0,87 & 3,0 & 21,7 & 97,0 & 22,5 \\
Karet 5 tahun & 10,9 & 22,0 & 37,4 & 73,0 & 48,3 \\
Karet 10 tahun & 26,7 & 48,0 & 28,6 & 52,0 & 55,3 \\
Karet 15 tahun & 80,2 & 70,0 & 31,2 & 30,0 & 111,5 \\
Karet 20 tahun & 80,6 & 87,0 & 12,0 & 13,0 & 92,6 \\
Hutan alami & 45,7 & 57,0 & 33,5 & 43,0 & 79,2 \\
Hutan Tanaman Industri & 75,5 & 84,1 & 14,2 & 15,9 & 89.7 \\
Eucalyptus 6-8 tahun & & & & & \\
\hline
\end{tabular}

Sumber: Saungreksawong et al. (2012), Du et al. (2015) diolah 
Tabel 2. Simpanan karbon dalam biomassa, tanah dan $\mathrm{CO}_{2}$ sequestration di negaranegara produsen karet alam

\begin{tabular}{lccrr}
\hline Negara & $\begin{array}{c}\text { Simpanan } \\
\text { Karbon dalam } \\
\text { Biomassa } \\
\text { (ton/ha) }\end{array}$ & $\begin{array}{c}\text { Simpanan } \\
\text { Karbon dalam } \\
\text { Tanah } \\
\text { (ton/ha) }\end{array}$ & $\begin{array}{c}\text { Total Simpanan } \\
\text { Karbon } \\
\text { (ton/ha) }\end{array}$ & $\begin{array}{c}\text { Rata-rata } \text { CO }_{2} \\
\text { Sequestration }\end{array}$ \\
\hline Thailand & 217,6 & 49,0 & 266,6 & (ton CO ha/tahun) \\
Malaysia & 258,8 & 54,4 & 313,2 & 33,26 \\
India & 142,0 & 23,0 & 165,0 & 38,33 \\
Indonesia & 139,0 & $45,0-60,0$ & $184,6-199,6$ & 28,84 \\
Ghana & 82,3 & 52,6 & 135,0 & 35,30 \\
Brazil & 47,4 & 105,6 & 153,0 & 40,11 \\
Kisaran & $47-259$ & $23-106$ & $135-313$ & $29-40$ \\
\hline
\end{tabular}

Sumber: International Rubber Research and Development Board (2009)

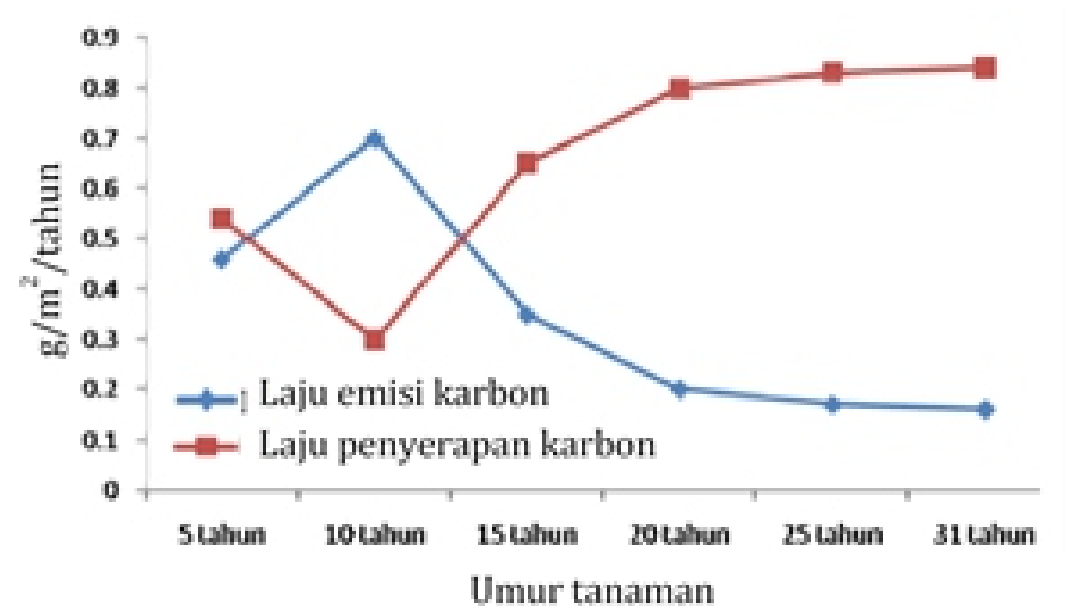

Gambar5. Laju emisi dan laju penyerapan karbon perkebunan karet

Walaupun pengukuran respirasi tanah tersebut hanya menggunakan metode yang sangat sederhana yaitu titrasi dan belum mewakili sepenuhnya jumlah karbon yang diemisikan di areal pertanaman, namun setidaknya data ini memperkuat bahwa tanaman karet adalah carbon sequestration yang bermanfaat secara ekonomi maupun lingkungan. Penelitian emisi karbon yang relatif lebih sempurna telah dilakukan di India oleh Annamalainathan et al. (2011) menggunakan metode eddy covariance dengan sensor yang dipasang pada tower setinggi 18 meter. Data yang dihasilkan dari metode ini adalah Net Ecosystem Exchange (NEE) yang secara langsung menggambarkan apakah kebun karet melepaskan atau menyerap karbon. Apabila tanaman menyerap $\mathrm{CO}_{2}$ maka flux akan menunjukkan nilai negatif (influx) dan menunjukkan nilai positif apabila melepaskan $\mathrm{CO}_{2}$ (efflux). 
Hasil penelitian tersebut menunjukkan bahwa fluks $\mathrm{CO}_{2}$ tahunan pada ekosistem perkebunan karet umur 4-5 tahun bernilai negatif, ini berarti bahwa jumlah karbon yang diserap oleh tanaman lebih besar dibanding karbon yang dilepaskan ke udara (Gambar 6). Rata-rata NEE dari penelitian tersebut adalah $11 \mathrm{~g} \quad \mathrm{CO}_{2} \mathrm{~g} / \mathrm{m}^{2} /$ hari atau 33,5 ton $\mathrm{CO}_{2} / \mathrm{ha} / \mathrm{tahun}$. Angka ini juga mengindikasikan bahwa ekosistem perkebunan karet bukan merupakan sumber (source) melainkan sebagai sink bagi $\mathrm{CO}_{2}$ atmosferik.

Penelitian mengenai $\mathrm{CO}_{2}$ di perkebunan karet telah dilakukan di beberapa lokasi di dunia namun tidak demikian dengan $\mathrm{N}_{2} \mathrm{O}$. Penelitian mengenai $\mathrm{N}_{2} \mathrm{O}$ sudah sangat berkembang pada komoditas lain terutama tanaman semusim yang menggunakan pupuk dengan jumlah yang cukup besar. Penggunaan pupuk nitrogen dan penambahan bahan organik di perkebunan karet yang cukup tinggi setiap tahunnya sangat potensial menghasilkan $\mathrm{N}_{2} \mathrm{O}$ yang dapat dilepaskan ke udara. Walaupun konsentrasi $\mathrm{N}_{2} \mathrm{O}$ di udara tidak setinggi $\mathrm{CO}_{2}$ tetapi gas ini memiliki daya rusak yang lebih kuat (298 kali) dibandingkan dengan $\mathrm{CO}_{2}$ sehingga mitigasi terhadap $\mathrm{N}_{2} \mathrm{O}$ dianggap sangat penting oleh para peneliti.
Di Indonesia pengukuran $\mathrm{N}_{2} \mathrm{O}$ di perkebunan karet pernah dilakukan di perkebunan rakyat di lahan gambut yang diaplikasikan pupuk kandang 4 ton/ha. Hasil penelitian tersebut menunjukkan bahwa besarnya $\mathrm{N}_{2} \mathrm{O}$ yang diemisikan sebesar 66-67 $\mathrm{kg} / \mathrm{ha} /$ tahun (Pradipta, 2012). Kondisi perkebunan karet rakyat di Indonesia yang pada umumnya kurang seragam dan pemeliharaan yang minim tentunya mempengaruhi data yang diperoleh. Data ini secara umum belum dapat mewakili emisi $\mathrm{N}_{2} \mathrm{O}$ asal perkebunan karet karena sebagian besar tanaman karet di Indonesia ditanam di lahan kering yang tentunya akan mengemisikan $\mathrm{N}_{2} \mathrm{O}$ yang berbeda dengan lahan gambut. Pengembangan penelitian yang lebih tajam masih sangat diperlukan terkait pengukuran emisi $\mathrm{N}_{2} \mathrm{O}$ di perkebunan karet. Sebagai negara penghasil karet alam Indonesia seyogyanya memulai dan fokus dalam penelitian gas rumah kaca. Penelitian gas memang membutuhkan biaya yang tidak sedikit namun peluang kerjasama dengan lembaga riset lain dan universitas masih sangat terbuka.

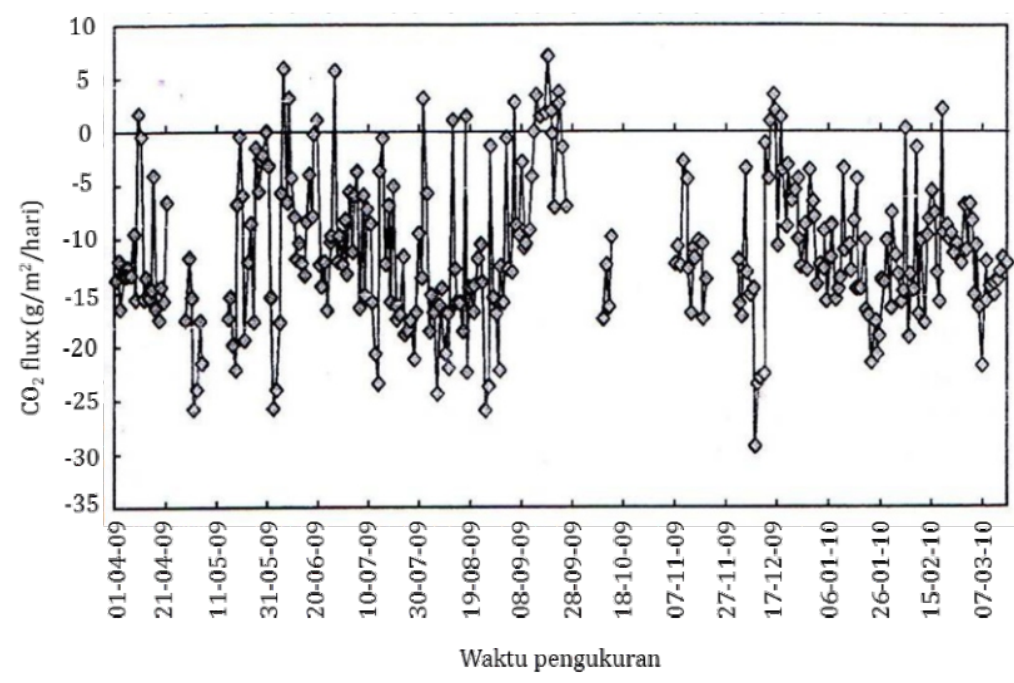

Gambar 6. Flux $\mathrm{CO}_{2}$ harian di perkebunan karet 


\section{Kesimpulan}

Tanaman karet merupakan tanaman penyerap $\mathrm{CO}_{2}$ yang cukup efektif yaitu sebesar 29-40 ton $\mathrm{CO}_{2}$ ha/tahun. Penelitian gas rumah kaca yang cukup komprehensif di perkebunan karet sudah dilakukan di beberapa negara seperti di Thailand dengan metode biometric dan di India dengan metode Eddy covariance. Namun penelitian yang lebih mendalam terkait emisi karbon dalam hubungannya dengan kultur teknis budidaya yang paling tepat dan aman bagi lingkungan masih sangat diperlukan. Selain emisi $\mathrm{CO}_{2}$, penelitian mengenai emisi gas lainnya seperi $\mathrm{N}_{2} \mathrm{O}$ (dinitrogen oksida) dan $\mathrm{CH}_{4}$ (metana) juga penting dilakukan mengingat rentang kondisi lingkungan penanaman karet yang cukup luas.

\section{Daftar Pustaka}

Anderson , J.P.E. (1982). Soil Respiration. In: A.L Page, R.H. Miller ; D.R. Keeney (eds). Method of Soil AnalysisPart 2, Chemical and Microbiological Properties. Madison : Soil Science Society of America, Inc Publisher.

Annmalainathan, K., Satheesh, P.R., and Jacob, J. (2011). Ecosystem flux measurements in rubber plantations. Natural Rubber Research, 24(1), 28-37.

Baldocchi, D.D. (2003). Assessing the eddy covariance technique for evaluating carbon dioxide exchange rates of ecosystem: past, present and future. Global Change Biology, 9, $1-14$

Barr, A.G., Black, T.A., Hogg, E.H., Kljun, N., Morgenstern, K., and Nesic, Z. (2004). Inter-annual variability in the leaf area index of a boreal aspen-hazelnut forest in relation to net ecosystem production. Agricultural and Forest Meteorology, 126,237255.

Chantuma, A., Kunarasiri, A., and Chantuma, P. (2012). Rubber new planting in Thailand: towards the world affected on climate change. Rubber Thailand Journal, 1, 40-47.
Chung-Wang, X., and Ceulemans, R. (2004). Allometric relationships for below and above ground biomass of young scots pines. Forest Ecology and Management, 203, 177-186.

Food and Agriculture Organization. (2006). FAO data 2006. Diakses dari http://faostat.fao.org

Gibs, H.K., Brown, S., and Niles, J.A. (2007). Monitoring and estimating tropical forest carbon stocks: making REDD a reality. Environmental Research Letters, 2, 1-13.

Gong, W., Yan, X., Wang, J., Hu, T., and Gong, Y. (2009). Long-term manure and fertilizer effects on soil organic matter fractions and microbes under a wheatmaize cropping system in northtern china. Geoderma, 149, 318-324.

Intergovernmental Panel on Climate Change. (2007). Contribution of Working Group III to the Fourth Assessment Report of the Intergovernmental Panel on Climate Change. Cambridge. In B.Metz, O.R. Davidson, P.R. Bosch, R. Dave, \& L.A.Meyer. Climate Change 2007. Cambridge: Cambridge University Press.

International Rubber Research and Development Board. (2009). The effect of climate change on NR cultivation and productivity. IRRDB conference $30^{\text {th }}$, Kuala Lumpur, November 2009.

Kirschbaum, M.U.F., Eamus, D., Gifford, R.M., Roxburgh, S.H., Sands, P.J. (2001). Definitions of some ecological terms commonly used in carbon accounting. In: M.U.F. Kirschbaum, and R. Mueller (eds). Net Ecosystem Exchange Workshop (pp.18-20). Canberra : Cooperative Research Centre for Greenhouse Accounting

Kool, D.M., Dolfing, J., Wrage, N., and Van Groenigen, J.W. (2011). Nitrifier denitrification as a distinct and significant source of nitrous oxide from soil. Soil Biology \& Biochemistry, 43, 74-178.

Lefsky, M.A., Cohen, W.B., Harding, D.J., Parker, G.G., and Acker, S.A. (2001). LiDAR remote sensing of above-ground biomass in three biomass. Global Ecology and Biogeography, 11,393-399. 
Lu, D. (2005). Aboveground biomass estimation using Landsat TM data in the Brazilian Amazon. International Journal of Remote Sensing, 26, 2509-2525.

Nelson, R., Krabil, W., and Tonelli, J. (1988). Estimating forest biomass and volume using airborne laser data. Remote Sensing of Environment. 24, 247-267.

Nhu, T.P., Ki, H.K., Parker, D., Eui, C.J., Jae, H.S., and Chang, S.C. (2012). Effect of beef cattle manure application rate on $\mathrm{CH} 4$ and $\mathrm{CO}_{2}$ emissions. Atmospheric Environment, 63, 327-336.

Nugroho, P.A., Shimizu, M., Nakamato, H., Nagatake, A., Suwardi, S., Sudadi, U., and Hatano, R. (2015). Nitrous oxide fluxes from soil under different crops and fertilizer management. Plant Soil Environment,61(9), 385-392.

Pradipta, A. (2012). Kajian penggunaan amelioran pupuk kandang terhadap emisi gas rumah kaca pada tanah yang diambil dari beberapa agroekosistem kebun karet di lahan gambut. Magister. Thesis,Institut Pertanian Bogor, Bogor.

Ravindranath, N.H., and Ostwald, M. (2008). Methods for estimating above ground biomass. In N.H. Ravindranath and M. Ostwald (eds). Carbon inventory methods: Handbook for greenhouse gas inventory, carbon mitigation and roundwood production projects (pp.113-114). Dordrecht: Springer Science + Business Media B.V.

Risk, N., Snider, D., and Wagner-Riddle, C. (2013). Mechanisms leading to enhanced soil nitrous oxide fluxes induced by freezethaw cycles. Canadian Journal of Soil Science, 93, 401-414.

Saungreksawong, C., Khamyong, S., Anongrat, N., and Pinthong, J. (2012). Growth and carbon stocks para rubber plantations on phonpisai soil series in Northeastern Thailand. Rubber Thailand Journal, 1, 1-18.
Shimizu, M., Marutani, S., Desyatkin, A.R., Jin, T., Hata, H., and Hatano, R. (2009). The effect of manure application on carbon dynamics and budgets in a managed grassland of Southern Hokkaido, Japan. Agriculture Ecosystemand Environment,130, 31-40.

Shimizu, M., Hatano, R., Arita, T., Kouda, Y., Mori, A., Maatsura, S., Niimi, M., Jin, T., Desyatkin, A.R., Kawamura, O., Hojito, M., and Miyata, A. (2013). The effect of fertilizer manure application on $\mathrm{CH}_{4}$ and $\mathrm{N}_{2} \mathrm{O}$ emissions from managed grasslands in Japan. Soil Science Plant Nutrition, 5, 69-86.

Steininger, M.K. (2000). Sateleite estimation of tropical secondary forest above ground biomass: data from Brazil and Bolivia. International Journal of Remote Sensing, 21, 1139-1157.

Susilawati, S. (2011). Pendugaan cadangan karbon (carbon stock) dan neraca karbon pada perkebunan karet. Skripsi, Institut Pertanian Bogor, Bogor.

Toma, Y., and Hatano, R. (2007). Effect of crop residue $\mathrm{C}: \mathrm{N}$ ratio on $\mathrm{N}_{2} \mathrm{O}$ emissions from gray lowland soil in Mikasa Hokkaido Japan. Soil Science Plant Nutrition,53, 198205.

Vashum, K.T., and Jayakumar, S. (2012). Methods to estimate above-ground biomass and carbon stock in natural forests- a review. Journal of Ecosystem Ecography,2:116.doi: 10.4172/2157-7625.1000116 